\title{
Ancient Egyptian Ma'at or Old Testament deed-consequence nexus as predecessors of ubuntu?
}

\begin{tabular}{|c|c|}
\hline \multicolumn{2}{|c|}{$\begin{array}{l}\text { Author: } \\
\text { Gerlinde Baumann }{ }^{1}\end{array}$} \\
\hline \multicolumn{2}{|c|}{$\begin{array}{l}\text { Evangelische Theologie, } \\
\text { Philipps-Universität Marburg, } \\
\text { Germany }\end{array}$} \\
\hline \multicolumn{2}{|c|}{$\begin{array}{l}\text { Correspondence to: } \\
\text { Gerlinde Baumann }\end{array}$} \\
\hline \multicolumn{2}{|c|}{$\begin{array}{l}\text { Email: } \\
\text { baumann@staff.uni-marburg. } \\
\text { de }\end{array}$} \\
\hline \multicolumn{2}{|c|}{$\begin{array}{l}\text { Postal address: } \\
\text { Lahntor 3, Marburg 35037, } \\
\text { Germany }\end{array}$} \\
\hline \multicolumn{2}{|c|}{$\begin{array}{l}\text { Received: } 18 \text { Feb. } 2015 \\
\text { Accepted: } 04 \text { May } 2015 \\
\text { Published: } 19 \text { June } 2015\end{array}$} \\
\hline \multicolumn{2}{|c|}{$\begin{array}{l}\text { How to cite this article: } \\
\text { Baumann, G., 2015, } \\
\text { 'Ancient Egyptian Ma'at } \\
\text { or Old Testament deed- } \\
\text { consequence nexus as } \\
\text { predecessors of ubuntu?', } \\
\text { Verbum et Ecclesia } 36(2) \text {, Art. } \\
\# 1429,4 \text { pages. http://dx.doi. } \\
\text { org/10.4102/ve.v36i2.1429 }\end{array}$} \\
\hline \multicolumn{2}{|c|}{$\begin{array}{l}\text { Dr. Gerlinde Baumann } \\
\text { is adjunct professor at } \\
\text { the Faculty of Protestant } \\
\text { Theology, Philipps-Universität } \\
\text { Marburg/Germany and } \\
\text { Research Associate of the } \\
\text { Department of Old Testament } \\
\text { Studies at the University of } \\
\text { Pretoria, South Africa. }\end{array}$} \\
\hline \multicolumn{2}{|c|}{$\begin{array}{l}\text { Research Participant in the } \\
\text { Ubuntu-Research project of } \\
\text { the University of Pretoria. }\end{array}$} \\
\hline \multicolumn{2}{|c|}{$\begin{array}{l}\text { Copyright: } \\
\text { (C) 2015. The Authors. } \\
\text { Licensee: AOSIS } \\
\text { OpenJournals. This work is } \\
\text { licensed under the Creative } \\
\text { Commons Attribution } \\
\text { License. }\end{array}$} \\
\hline \multicolumn{2}{|l|}{ Read online: } \\
\hline 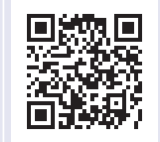 & $\begin{array}{l}\text { Scan this QR } \\
\text { code with your } \\
\text { smart phone or } \\
\text { mobile device } \\
\text { to read online. }\end{array}$ \\
\hline
\end{tabular}

The Ancient Egyptian concept of $M a^{\prime} a t$ shows some analogies to the concept of ubuntu. Both concepts seem to presuppose that people in a given society are willing to act for each other. In Bible exegesis, the concept of $M a^{\prime}$ at has attracted interest in connection with the Old Testament deed-consequence nexus (i.e. good consequences follow good deeds). The article looks at significant parallels between $u b u n t u, M a^{\prime} a t$ and the deed-consequence nexus. Its aim is to outline questions that have been discussed in the context of those two ancient concepts and that could be helpful for future research on $u b u n t u$.

\section{Introduction}

According to Assmann (1990:65), 'the reward of one who acts lies in that one acts for him'. This sounds similar to the core sentence of the Zulu proverb about ubuntu: 'I am what I am because of who we all are'. What Assmann quotes is, however, not a recent African saying, but is related to the Ancient Egyptian concept of Ma'at. This concept has played an important role in the German-speaking discussion on Old Testament thought for roughly two decades. It has been used to shed light on the so-called deed-consequence nexus in the Old Testament.

Considering that at first glance the concept of $M a^{\prime} a t$ shows parallels to the present-day concept of ubuntu, and because, via Ma'at, the Old Testament deed-consequence nexus can also be compared with $u b u n t u$, it could be worthwhile to contrast all three concepts. The focus of this article, therefore, will be to make a rough analysis whilst taking some initial steps to outline some questions for further, deeper research. It is not intended to establish any kind of historical link between the three phenomena. The comparison of the three phenomena will be done on the basis of a brief and juridical description of ubuntu (Lamont 2011) on the one hand, and on the German-speaking research discussion about $M a^{\prime} a t$ and the Old Testament deed-consequence nexus, on the other hand. In the case of Ma'at, this is Assmann's (1990) volume on the topic, and with regard to the Old Testament deed-consequence nexus, three research articles in particular (Baltzer \& Krüger 1997; Janowski 1994; Koch 1998). Therefore, the focus of this article will not be to deepen the scholarly discussion of the broader phenomenon of $u b u n t u$, nor to study the (Egyptian or Old Testament) original texts, but rather to examine short descriptions in secondary literature.

\section{Ubuntu and the Ancient Egyptian concept of $M a^{\prime} a t$}

For the parallels between $u b u n t u$ and $M a^{\prime} a t$, let us start with the description of some aspects of ubuntu from the viewpoint of South African judge, Colin Lamont (2011):

Ubuntu is a concept which:

- is to be contrasted with vengeance;

- dictates that a high value be placed on the life of a human being;

- is inextricably linked to the values of and which places a high premium on dignity, compassion, humaneness and respect for humanity of another;

- dictates a shift from confrontation to mediation and conciliation;

- dictates good attitudes and shared concern;

- favours the re-establishment of harmony in the relationship between parties and that such harmony should restore the dignity of the plaintiff without ruining the defendant;

- favours restorative rather than retributive justice;

- operates in a direction favouring reconciliation rather than estrangement of disputants;

- works towards sensitising a disputant or a defendant in litigation to the hurtful impact of his actions to the other party and towards changing such conduct rather than merely punishing the disputant;

- promotes mutual understanding rather than punishment;

- favours face-to-face encounters of disputants with a view to facilitating differences being resolved rather than conflict and victory for the most powerful;

- favours civility and civilised dialogue premised on mutual tolerance. (pp. 11-12) 
This is not a thorough ethical description, but rather a short juridical view of ubuntu; nevertheless, it serves our purpose, as some of the very important aspects of $u b u n t u$ are highlighted here.

Let us then have a look at the Egyptian goddess and concept $M a^{\prime}$ at. This has been analysed and systematised by the German Egyptologist Jan Assmann in his 1990 volume of the same name. Up to then, for the most part, $M a^{\prime} a t$ had primarily been recognised as an Ancient Egyptian deity. Assmann (1990:57-91) points out that $M a^{\prime} a t$, at the same time, is also a concept that formed the basis of social interaction in Ancient Egypt. The concept of $M a^{\prime} a t$ is found in texts of diverse genres from the time of the Old, Middle and New Kingdoms (about 2700 BCE - 1000 BCE) and is one of the core beliefs of Egyptian religion and ethics. One very important text for Assmann (1990:65) is a saying written on the stela of King Neferhotep, who was a member of the 13th dynasty (about 1700 BCE): 'The reward of one who acts lies in the fact that one acts for him; this is Ma'at in the heart of god'. In Assmann's description, this concept of Ma'at mostly covers three aspects:

- $\quad$ it is to act for each other (active solidarity) ${ }^{1}$

- it is to speak and to listen to each other (communicative solidarity $)^{2}$

- it is to think of each other (intentional solidarity) ${ }^{3}$.

Assmann summarises this concept under the heading of connective justice. ${ }^{4}$

Now that we have gained an impression of the concepts of ubuntu and Ma'at: which parallels do we find between the two of them? Seeing that $M a^{\prime}$ 'at is more about 'acting together' and ubuntu is more about 'being together', they cannot be considered identical. What makes it possible to compare both phenomena? First and foremost, both are closely connected to mutuality in human behaviour. On the basis of Judge Lamont's (2011:11-12) list of ubuntu aspects, especially numbers 1, 4 and 6-10 bear parallels with $M a^{\prime} a t$ : it is a counter-concept to vengeance (1) and is more interested in mediation than in confrontation (4); its focus is on harmony, reconciliation, restorative justice, sensitising and mutual understanding (6-10). These aspects are related to the legal system, but they also provide a perspective of the underlying cultural views. The aspects of $M a^{\prime}$ at analysed by Assmann focus on the wider perspective of society in general, with special attention on political aspects, rulership and religion, but the juridical angle is also included. Thus we need to keep in mind that the focus in both descriptions is different, which means that there is still room for further analysis.

\footnotetext{
1.'Füreinander-Handeln' (Assmann 1990:64-69).

2.'Zueinander-Sprechen' and 'Aufeinander-Hören' (Assmann 1990:85).

3.'Gemeinsinn' (Assmann 1990:85)

4. 'Konnektive Gerechtigkeit' or iustitia connectiva (e.g. Assmann 1990:67, 69, 283).
}

We have already come across the aspect of mutuality or mutual solidarity. But although that might be the case with $u b u n t u$, the Ancient Egyptian $M a^{\prime}$ at concept is closely related to a specific group of people in a specific social system, as Assmann (1990:97-109, 242-252) points out. It is a specific virtue for or of state officials, judges and kings; they are the ones who are primarily required to keep $M a^{\prime} a t$, to be oriented towards $M a^{\prime} a t$ and to live (the spirit) of $M a^{\prime}$ at (cf. Quack 2006:§2). With regard to this hierarchichal aspect, Assmann (1990:103, 245, 247) speaks of vertical justice - that the stronger protect the weaker, and in return the weaker give their obedience to the stronger. He explains:

Ma'at can only exist in stratified societies. As a principle of protection, it presupposes 'the weak' and their need for protection; as a principle of just distribution, it presupposes the prior collection of what can be distributed; and as a principle of charity, it presupposes 'the poor'. (Assmann 1990:103)

An important role in this concept is played by the king as mediator and executor of Ma'at (Assmann 1990:200-212): 'Ma'at only 'works' within the institutional frame of rulership' (p. 254). A question for further research might be to examine if this also applies to $u b u n t u$, or if $u b u n t u$ is also applicable to more equal or less stratified societies.

Another aspect of $\mathrm{Ma}^{\prime}$ at is its relationship to religion. Are the three kinds of solidarity enforced or maintained by the deities, in some kind of automatism, or is that not the case? In Assmann's (1990:243) eyes, there is no automatism where the actual social practice of $M a^{\prime} a t$ is maintained or guaranteed by the deity $M a^{\prime} a t::^{5}$ 'Ma'at is midway between morality and religion'. Could this point to the fact that ubuntu also has religious aspects, perhaps unseen or invisible ones?

Related to this is the question of whether Ma'at should be classified as an abstract philosophical concept or rather as some kind of world order. Although this position has been expressed in earlier research, Assmann (1990) has a different opinion on this:

$M a^{\prime} a t$ is not inherently 'world order', but solidarity, humanity, reliability, altriusm. Ma'at is a norm of behaviour. 'World order' cannot be established in everyday behaviour. World order is something that is given and nothing that is required. (p. 268)

Is there some aspect of 'world order' in $u b u n t u$, or must it be categorised in a different way?

\section{Ubuntu and the Old Testament deed-consequence nexus}

As already indicated, there is no direct connection between the Old Testament deed-consequence nexus and ubuntu in the strict sense. Some of the biblical aspects, however, can

5.This is illustrated by Assmann (1990:209) by the example of the king, whose deeds are only initiated by the deity and not completely guided by it. 
be connected with ubuntu through the Ancient Egyptian concept of $M a^{\prime} a t$.

What is the deed-consequence nexus? In short, it is the relationship between one's deeds and the consequences these deeds have. ${ }^{6}$ In quite a number of Old and New Testament texts as well as in the Ancient Near East, it is beyond question that such a nexus exists. In some texts, however, this connection seems to be called into doubt. In the biblical texts, this would primarily be the book of Job: Job is a righteous man, but nevertheless has to suffer.

Assmann's systematisation of $M a^{\prime} a t$ has stimulated certain efforts in Old Testament scholarship to relate it to the deedconsequence nexus which can particularly be found in Old Testament Wisdom writings (Pr; Job). The first of these efforts focuses on the fact that a social component should possibly be added to the biblical version of the deed-consequence nexus. Janowski (1994) summarises Assmann's thoughts and then applies it to a number of verses from the biblical book of Proverbs:

Justice does not occur by itself, but is dependent on 'acting for each other' and 'thinking of each other'. Its basis is the principle of mutuality, and is not some 'natural consequence' of a good deed, but a function of social action. (p. 261)

For the biblical book of Job, the relationship between the deed-consequence nexus and social action has also been highlighted by Baltzer and Krüger (1997). ${ }^{7}$ In contrast to other exegetes, they do not think that Job's problem is predominantly about the fact that the deed-consequence nexus here is completely denied, which first of all would be an epistemological or theological problem and not a social one. Taking the example of Job 19:13-19, they try to illustrate that 'Job's misfortune is (at least also) related to a lack of social solidarity' (Baltzer \& Krüger 1997:31). With respect to $u b u n t u$, the question arises as to whether the existence or nonexistence of social solidarity might play an important role in the opportunities to put ubuntu into practice.

The second aspect here is also problematised by Baltzer and Krüger. They discuss if the specific vertical aspects of Ma'at regarding social hierarchies can also be found in Old Testament thought, especially in the book of Job (Baltzer \& Krüger 1997:30-36). In the eponymic biblical book, Job is depicted as a rich and righteous man who is particularly generous toward the poor - with Assmann, one could say that he practises vertical justice. Job, through no fault of his own, then falls into poverty, and almost none of those whom he formerly supported come to his aid. According to Baltzer and Krüger (1997), the book of Job does indeed criticise the

6.A short and instructive outline of the current Oid Testament research discussion focusing on divine 'retribution' (the term used in the earlier research discussion)
and including Assmann's thoughts can be found in Groenewald (2003:105-110). For a more elaborate survey of the German-speaking discussion, refer to Freuling (2004:1-32).

7.Baltzer and Krüger (1997:28) also point out the fact that in the Old Testament discussion on the older term 'retribution', Knierim (1965:77-79) was one of the first to establish the link between the deed-consequence nexus and society. lack of horizontal justice, but not the lack of solidarity from the side of the poor:

In view of the 'horizontal' solidarity between socially equal persons ... [the text] shows critique of its denial. In contrast, in ... [the text] a critical view of the social conditions is indicated, under which 'vertical' solidarity is justified and legitimated. (p. 35)

If this is true, it differs from $M a^{\prime} a t$. The deed-consequence nexus is perhaps not only applicable to strictly stratified social conditions, but also to more equal ones, and it allows for criticism of socially unjust conditions. As for $u b u n t u$, this could mean the question regarding a necessary connection to stratified societies should be addressed, as already suggested above.

Thirdly and finally, there is a controversial debate whether God or a religious element is an essential part of the deedconsequence nexus. The discussion questions if the older paradigm of (divine) retribution can really be dismissed in favour of the deed-consequence nexus. Koch, in his earlier works, is of the opinion that there is no such 'doctrine of retribution', as the crucial aspects of such a doctrine cannot be found in the Old Testament. In Koch's model, God assumes the position of a kind of 'midwife' in bringing the deed-consequence nexus into effect; God does not quasiautomatically 'guarantee' that everyone whose actions are good can also expect good consequences in his or her life (Koch 1955). ${ }^{8}$ In contrast to this, Janowski tries to make plausible that God plays a more important role in the realisation of the deed-consequence nexus, although this realisation does not happen automatically; Janowski's most important biblical reference is Proverbs 25:21f (Janowski 1994:269-270). In this context, he uses the systematic theological idea of God's mercy, which is not at the disposal of man. This, however, has been contradicted by Baltzer and Krüger (1997:35): 'It is for human beings to care for the 'just order' of social reality!' It is seen as the task of all human beings to establish just social conditions that allow the deed-consequence nexus to be brought into effect. Similarly, Koch (1998:57-58; footnote 54) has also contradicted Janowski, mostly regarding the aspect of God's supposed 'mercy which is not at the disposal of man'. Koch, however, thinks that beyond the deedconsequence nexus, there is some kind of world view which is established and maintained by God. In addition, Koch also sees more human influence on the realisation of the deedconsequence nexus than Janowski does. It seems that the deed-consequence nexus is part of the Old Testament (and Ancient Near Eastern) world view which presupposes divine action in the creation and preservation of the world, but not as a kind of automatism in every single act performed by human beings. Because in the Ancient Near East (including Ancient Egypt and Ancient Israel), all concepts are more or less closely related to religion and to deities, it is difficult to say whether the deed-consequence nexus could be thought of without divine involvement. With regard to $u b u n t u$, again,

8.Koch's main point of criticism is that in earlier research, it is often spoken of an Old Testament 'dogma of retribution'; Koch's (1955) term for his own counter concept is 'schicksalwirkende Tatsphäre', which Groenewald (2003:106) translates as 'fatecharged sphere of activity'. 
the question could be if there is an underlying or unseen religious dimension.

\section{Conclusion \\ Questions for future research on ubuntu}

After looking at the discussion about the Ancient Egyptian concept of $M a^{\prime} a t$ and the Old Testament deed-consequence nexus, there are two sets of questions which could be interesting to examine in future research on $u b u n t u$.

Firstly, is ubuntu related to a specific form of society? Is $u b u n t u$ a general notion of mutuality amongst human beings, or is it tied to specific forms of society? Is ubuntu perhaps only (or even better) applicable to smaller social units, but not to larger societies? And with regard to a different facet of this question: does $u b u n t u$ have a vertical dimension? Could it be that $u b u n t u$ - like the concept of $M a^{\prime} a t$ - is only applicable to stratified and hierarchical societies, and not to more equal ones? Or is the opposite the case? How do social conflicts and problems inflict ubuntu? As we saw earlier, the likelihood that $M a^{\prime} a t$ or the deed-consequence nexus are brought into effect depends on a certain level of solidarity in a society. In the event that a society experiences severe problems or a crisis, do the opportunities to practice ubuntu decline?

Secondly, what is the character of ubuntu? Is it an ethical concept, or could, to some extent, a deity be involved in human efforts to perform ubuntu? Does ubuntu have a religious dimension, perhaps only an invisible one? Might the actual practice of $u b u n t u$ be guaranteed by a deity? Or should ubuntu be classified as a kind of world order which is thought to function automatically?

Based on this article, which is only meant to raise some introductory questions, it is not possible to state that
$M a^{\prime} a t$ or the deed-consequence nexus could be seen as predecessors of ubuntu. In comparing the concepts in future research, it should also be kept in mind that the cultural contexts are significantly different. Personally, however, my hope is that these questions which have been raised from discussions about concepts from a distant past may shed some light on the present-day southern African concept of ubuntu.

\section{Acknowledgements Competing interests}

The author declares that she has no financial or personal relationships which may have inappropriately influenced her in writing this article.

\section{References}

Assmann, J., 1990, Ma'at. Gerechtigkeit und Unsterblichkeit im Alten Ägypten, Beck, München.

Baltzer, K. \& Krüger, Th., 1997, 'Die Erfahrung Hiobs: "Konnektive" und "distributive" Gerechtigkeit nach dem Hiob-Buch', in H.T.C. Sun \& K.L. Eades (eds.), Problems in biblical theology. Essays in honor of Rolf Knierim, pp. 27-37, William B. Eerdmans Publishing Company, Grand Rapids.

Freuling, G., 2004, 'Wer eine Grube gräbt ...' Der Tun-Ergehen-Zusammenhang und sein Wandel in der alttestamentlichen Weisheitsliteratur, Neukirchener Verlagsges, Neukirchen-Vluyn.

Groenewald, A., 2003, Psalm 69: Its structure, redaction and composition, LIT, Münster.

Janowski, B., 1994, 'Die Tat kehrt zum Täter zurück. Offene Fragen im Umkreis des 'Tun-Ergehen-Zusammenhangs', Zeitschrift für Theologie und Kirche 91, 245-271.

Koch, K., 1955, 'Gibt es ein Vergeltungsdogma im Alten Testament?', Zeitschrift für Theologie und Kirche 52, 1-42.

Koch, K., 1998, 'Sädäq und Ma'at: Konnektive Gerechtigkeit in Israel und Ägypten?', in J. Assmann (ed.), Gerechtigkeit. Richten und Retten in der abendländischen Tradition und ihren altorientalischen Ursprüngen, pp. 37-64, Fink, München.

Knierim, R., 1965, Die Hauptbegriffe für Sünde im Alten Testament, Gütersloher Verlagshaus, Gütersloh.

Lamont, Judge C., 2011, 'The equality court', Afri-Forum and another vs. Malema and others, viewed 18 February 2015, from http://en.wikipedia.org/wiki/ Ubuntu_\%28philosophy\%29\#cite_note-Lamont-15

Quack, J. Fr., 2006, Maat, viewed n.d., from http://www.wibilex.de 